\section{Nauplius}

The Journal OF The Brazilian Crustacean Society

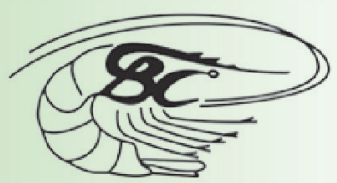

e-ISSN 2358-2936

www.scielo.br/nau www.crustacea.org.br

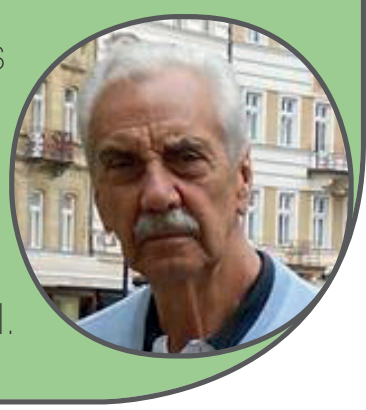

\title{
Allometric growth, sexual maturity and reproductive cycle of Aegla castro (Decapoda: Anomura: Aeglidae) from Itatinga, state of São Paulo, southeastern Brazil
}

Bruno Fernandes Takano ${ }^{1}$, Felipe Pereira de Almeida Cohen ${ }^{1}$, Adilson Fransozo ${ }^{2}$, Roberto Munehisa Shimizu ${ }^{3}$ and Sérgio Luiz de Siqueira Bueno ${ }^{1}$

1 Departamento de Zoologia, Instituto de Biociências, Universidade de São Paulo. Rua do Matão, travessa 14, n. 101. 05508-900, São Paulo, Brazil.

BFT E-mail: brunotakano@yahoo.com.br

FPAC E-mail: fcohen.bio@gmail.com

SLSB E-mail: sbueno@ib.usp.br

2 Departamento de Zoologia, Instituto de Biociências, Universidade Estadual Paulista. Distrito de Rubião Júnior, s/ nº. 18618-000 Botucatu, São Paulo, Brazil.

AF E-mail: fransozo@ibb.unesp.br.

3 Departamento de Ecologia, Instituto de Biociências, Universidade de São Paulo. Rua do Matão, travessa 14, n. 101. 05508-900, São Paulo, Brazil.

RMS E-mail: rshimizu@ib.usp.br

ZOOBANK http://zoobank.org/urn:lsid:zoobank.org:pub:B73E999A-A9D6-41D0-

A369-5DEB6FBD5D61

CORRESPONDING AUTHOR Sérgio Luiz de Siqueira Bueno sbueno@ib.usp.br

SUBMITTED 19 February 2016 ACCEPTED 27 April 2016 PUBLISHED 9 September 2016

Guest Editors

Maria Lúcia Negreiros-Fransozo and Adilson Fransozo

DOI $10.1590 / 2358-2936 e 2016010$

\section{Abstract}

Allometric growth of chelae dimensions was analyzed to assess the average size at the onset of morphometric maturity (ASOMM) and sexual dimorphism regarding the pair of chelae in the Aegla castro. Both adult males and females are heterochelous with the most robust chela occurring predominantly on the left side. Both chelae are larger in males than they are in females of similar size, thus characterizing these structures as sexually dimorphic traits. The ASOMM estimated for males and females were 10.91 and $10.03 \mathrm{~mm}$ of carapace length (CL), respectively. The increase in variability of chelae dimensions in post-pubertal males led to the recognition of two morphotypes 
(I and II). Temporal variation in the proportions of morphotype II males in relation to females showing late ovarian development was synchronous, making the sexually functional nature of these males evident. The average size at the onset of functional maturity (ASOFM) estimated for males (based on the transition from morphotype I to morphotype II) and females (based on the detection of late ovarian development or eggs) were 17.12 and $12.59 \mathrm{~mm}$ of CL, respectively. Ovigerous females were sampled from April through August 2007, characterizing a marked seasonal reproductive period lasting for 5 months.

\section{KEY WORDS}

Aeglids, morphometric maturity, functional maturity, adult male morphotypes.

\section{INTRODUCTION}

The family Aeglidae Dana, 1852 includes two extinct genera from marine sediment from the Pacific region, Haumuriaegla Feldmann, 1984 and Protaegla Feldmann, Vega, Applegate \& Bishop, 1998, and one extant genus, Aegla Leach, 1820 found in freshwater habitats (Feldmann, 1984; Bond-Buckup and Buckup, 1994; Feldmann et al., 1998; Bond-Buckup et al., 2008; McLaughlin et al., 2010).

Aegla is unique among anomurans because all 78 species described so far (see checklist by McLaughlin et al., 2010, augmented by description of new species published afterwards by Santos et al., 2012; 2013; 2014; 2015) are endemic to continental South America from latitude $70^{\circ} \mathrm{S}$, in Chile to latitude $20^{\circ} \mathrm{S}$ in Brazil (Bueno et al., 2007; Oyanedel et al., 2011), and are entirely adapted to freshwater habitats, such as lakes, rivers and streams (Schmitt, 1942; Martin and Abele, 1988; Bond-Buckup and Buckup, 1994). Most species are found in epigean habitats (Bond-Buckup et al., 2008) but few species are obligate inhabitants of subterranean habitats (Türkay, 1972; Bond-Buckup and Buckup, 1994; Fernandes et al., 2013).

Morphometric and functional maturities are different approaches to access sexual maturity in decapod crustaceans. The former is associated with the puberty molt and marks the transition from the juvenile into the adult phase, whereas the latter refers to sexually matured individuals that successfully take part in the reproductive process (see López-Greco and Rodríguez, 1999 for review on sexual maturity in decapods). Allometric growth analysis has been often employed in determining the average size at the onset of morphometric maturity of aeglids species (Colpo et al., 2005; Viau et al., 2006; Bueno and Shimizu, 2009; Oliveira and Santos, 2011; Trevisan and Santos, 2012; Copatti et al., 2015).
Based on significant change in the allometric growth coefficient during adulthood, Bueno and Shimizu (2009) recognized two sequential adult male morphotypes (I and II) in a population of Aegla franca Schmitt, 1942: Morphotype II differed from the previous morphotype in having larger and more robust pair of chelae. Temporal variation in the proportions between morphotypes in relation to the reproductive cycle of the species indicated that morphotype II males were associated with the acquisition of functional maturity in that sex. For females, the occurrence of full ovarian maturation and/or ovigerous condition have been employed in the determination of the size of functional maturity of aeglid species (Swiech-Ayoub and Masunari, 2001b; Viau et al., 2006; Bueno and Shimizu, 2008; Rocha et al., 2010; Grabowski et al., 2013).

Aegla castro Schmitt, 1942 is endemic to Brazil and its distribution range includes tributaries on both sides of the Paranapanema River basin, comprising the southern region of the state of São Paulo and the northeastern region of the state of Paraná (see BondBuckup and Buckup, 1994 for names of location). Field studies conducted on this species are scarce and focus mainly on population structure and reproduction (Swiech-Ayoub and Masunari, 2001a; 2001b; Fransozo et al., 2003).

In the present paper, we investigate the size at the onset of morphometric and functional maturity in males and females of $A$. castro from Itatinga county, state of São Paulo, Brazil. We report the occurrence of sequential adult male morphotypes and their relationship with the reproductive cycle in the population. Finally, we also provide results regarding sexual dimorphism, the heterochelous condition and handedness of the pair of chelipeds. 


\section{Material and Methods}

Study site, sampling procedures and field data Specimens of $A$. castro were sampled monthly from March 2007 through February 2008 from a shallow $50 \mathrm{~m}$ long section of the Itaúna Stream $\left(23^{\circ} 09^{\prime} 48.6^{\prime \prime}\right.$ $\mathrm{S} 48^{\circ} 37^{\prime} 49.8^{\prime \prime} \mathrm{W}$; $306 \mathrm{~m}$ above sea level), county of Itatinga, state of São Paulo. This stream belongs to the Paranapanema River basin, which, in turn, is one of the main drainage systems that make up the Upper Paraná Basin.

Aeglids were collected with traps following the procedures described in Bueno et al. (2007). Commercial fish flavoured dried cat food was used as bait, and traps were set late in the afternoon and checked for captured animals in the following morning. Hand sieves (mesh size: $1 \mathrm{~mm}$ ) were also used to sample additional specimens, including small juveniles (carapace length $<6 \mathrm{~mm}$ ) which are not representatively collected by traps. Sieves were kept submerged in oblique position while small rocks and pebbles next to them were manually removed, so as to dislodge the juveniles which were retained by the sieve as they were carried away by the water current.

Each aeglid was sexed based on the position of the gonopore openings (coxa of the third pair of pereiopods in females and of the fifth pair of pereiopods in males) and the presence of pleopods in females (absent in males) (Martin and Abele, 1988).

\section{Measurements (Fig. 1)}

Carapace length (CL), rostrum not included, was measured from the orbital sinus to the mid-posterior border. Carapace length with rostrum included (CLR) was also measured as the distance from the tip of the rostrum to the mid-posterior border. The relationship between these two measurements was employed to compare the results of the present study with those of other authors in which the measurement of CLR was adopted instead. Straight line equations describing this relationship were obtained with linear regression, separately for males and females and compared with analysis of covariance (ANCOVA).

Chelipeds (first pereiopods): Propodus length of each chela was measured from the outer angle of the proximal border to the distal end of the fixed finger. Propodus height was measured as the cross distance from midpoint of the palmar crest border to the opposite border of palm.
All measurements were taken in loco from live specimens with digital caliper to the nearest $0.01 \mathrm{~mm}$, except for specimens with less than $8 \mathrm{~mm} C L$ which were measured with a calibrated ocular scale adjusted to a dissecting scope to the nearest $0.1 \mathrm{~mm}$. Females were inspected for late ovarian development condition (Bueno and Shimizu, 2008) or eggs attached to the pleopods. The reproductive period was defined as the sequence of months in which ovigerous females were sampled.

Voucher material was deposited at the Museum of Zoology of the University of São Paulo (MZUSP \# 18841). All other sampled specimens were returned alive to the stream after all measurements and field observations were concluded.

\section{Data analysis}

Relative growth analyses were based on the allometric equation $y=a C L b$ (where $y=$ chela dimension; $b$ $=$ allometric growth coefficient; $a=$ intercept on $y$ axis), converted to the linear form $\ln y=b \ln C L+\ln a$ (Hartnoll, 1978; 1982; 1985). Data from animals showing clear state of regeneration or lacking one of the chelipeds or the pair of chelipeds altogether were excluded from all analyses. Bivariate dataset (selected dependent variable $v s$. independent variable) were grouped according to major and minor chelae criterion. The procedure to separate data into juvenile and adult groups differed for each sex and followed the analytical procedures described in detail by Bueno and Shimizu (2009) for A. franca.

Males: Visual inspection of $\ln$ [chela dimension] vs. $\operatorname{lnCL}$ scatter plots indicated a marked increase in variability in chelae dimensions among large adult specimens (see Fig. 2A), suggesting the occurrence of two morphotype groups of adult males (= chelae size dimorphism) in the population. The smallest $\mathrm{CL}$ at which such increase in variability was detected $(\mathrm{CL}=15.96 \mathrm{~mm}$; $\operatorname{lnCL}=2.77)$ was considered as the lower limit of data points used to proceed with the separation of data set of large adult specimens into two superimposed groups. The non-hierarchical $\mathrm{K}$-means clustering method (Legendre and Legendre, 1998) was applied on the bivariate data set consisting of standardized residuals of $\ln$ [chela dimension] vs. $\operatorname{lnCL}$ regression (variable 1) and $\operatorname{lnCL}$ (variable 2), followed by discriminant analysis to re-allocate any 


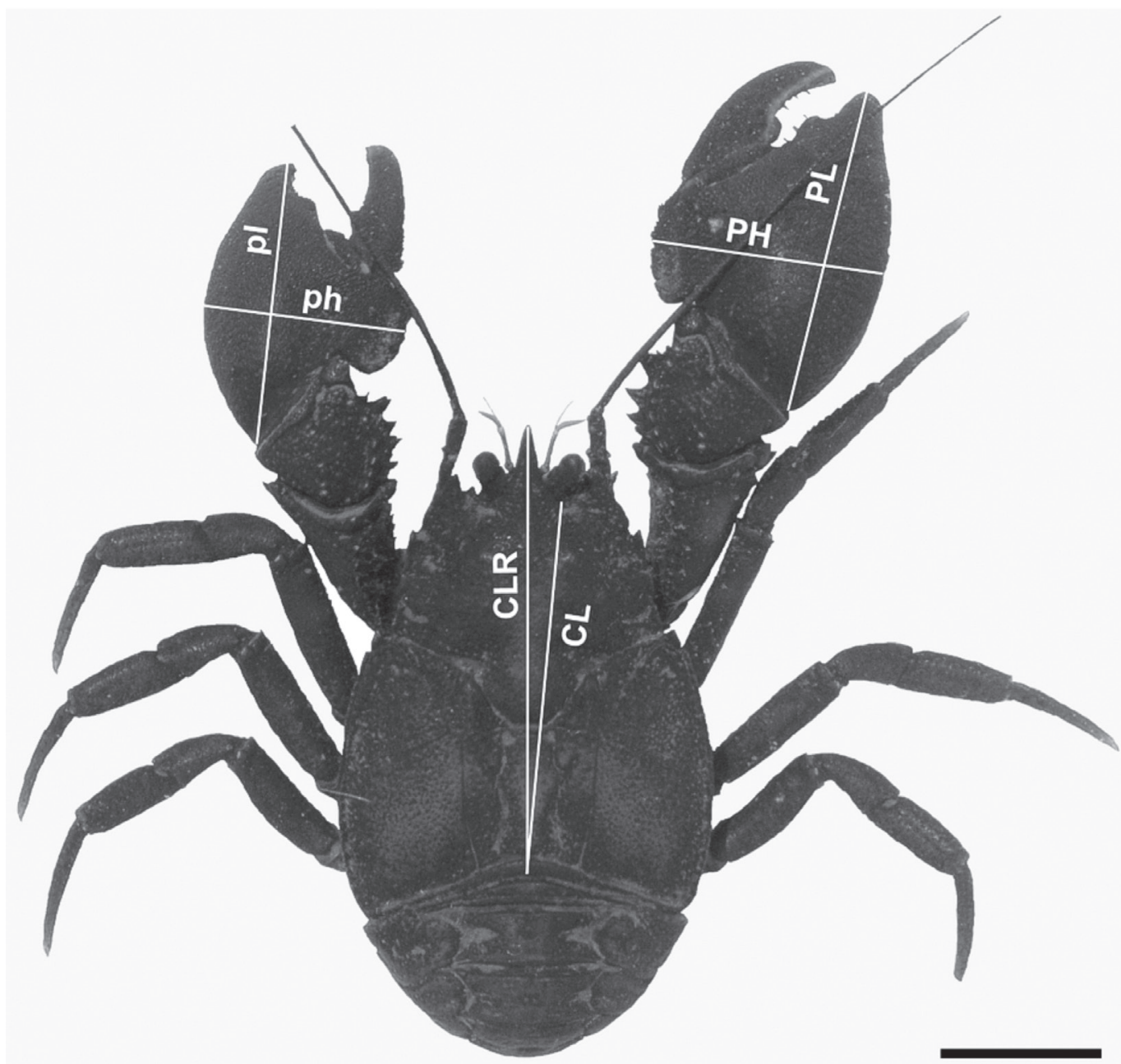

Figure 1. Aegla castro. Live male specimen. Carapace measurements: carapace length from orbital sinus to posterior border, rostrum excluded (CL); carapace length with rostrum included (CLR). Chelae measurements: propodus length (pl) and propodus height $(\mathrm{ph})$ of minor chela; propodus length $(\mathrm{PL})$ and propodus height $(\mathrm{PH})$ of major chela. Scale bar $=10 \mathrm{~mm}$.

previously misclassified data (Legendre and Legendre, 1998). After all points associated with larger chelae dimensions (= morphotype II group, sensu Bueno and Shimizu, 2009) have been identified and isolated, all remaining data were used in the separation of points into juveniles and morphotype I adults (sensu Bueno and Shimizu, 2009). This time, the $K$-means clustering and the discriminant analysis were performed on $\ln$ [chela dimension] vs. $\operatorname{lnCL}$ data points.

Females: Differently to what had been observed in large adult males, visual inspection of $\ln$ [chela dimension] vs. $\operatorname{lnCL}$ scatter plots did not indicate any marked increase in variability in chelae dimensions in large adult female specimens (Fig. 2B). Thus, the same procedure used for separating male juveniles from morphotype I adult males was employed. The $\mathrm{K}$-means clustering and the discriminant analysis on both male and female data points were carried out with the software PAST version 1.62 (Hammer et al., 2001).

For every life stage group data recognized, linear regression was applied to $\ln$ [chela variable] vs. $\operatorname{lnCL}$ data set. Data with correspondent absolute values of standardized residuals $(z)$ higher than $|2.57|(p<0.01)$ were regarded as outliers and were excluded from all subsequent analyses. Specific Student's $t$-tests were employed to compare regression slopes and elevations (when necessary) between juvenile and adult (only morphotype I in the case of males) data groups of both sexes and between the two adult male morphotypes data groups.

The state of allometry of chelae dimensions in each life stage was determined by testing the null hypothesis $H_{0}: b$ (= slope of the allometric equation $)=1.00$ with Student's $t$-test. Whenever $H_{0}$ was rejected, growth was 
considered positively allometric $(b>1)$ or negatively allometric $(0<b<1)$; when $H_{0}$ was not rejected, growth was considered isometric (see Hartnoll, 1978; 1982; Martínez-Mayén et al., 2000).
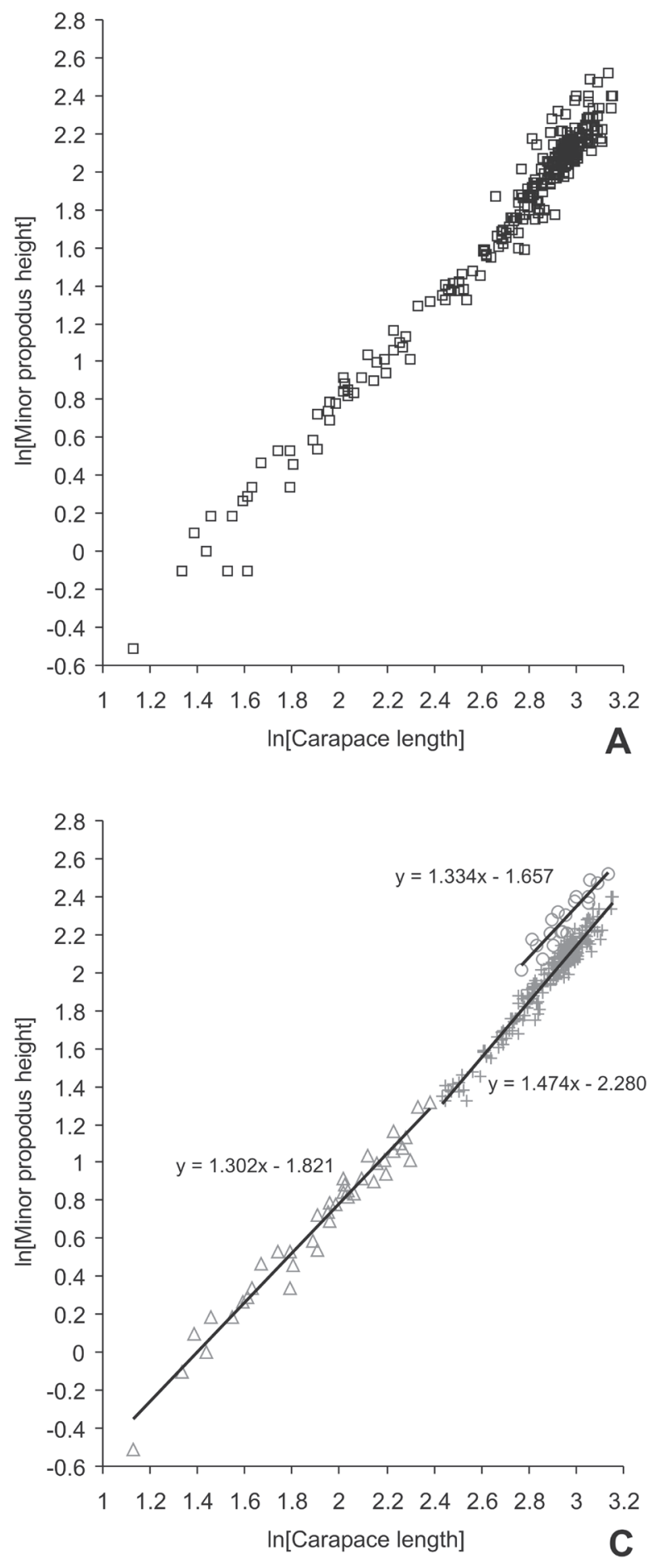

The size at the onset of morphometric maturity in each sex, defined as the CL at which 50\% of sampled individuals were considered as adults was estimated by interpolation of the equation obtained by applying
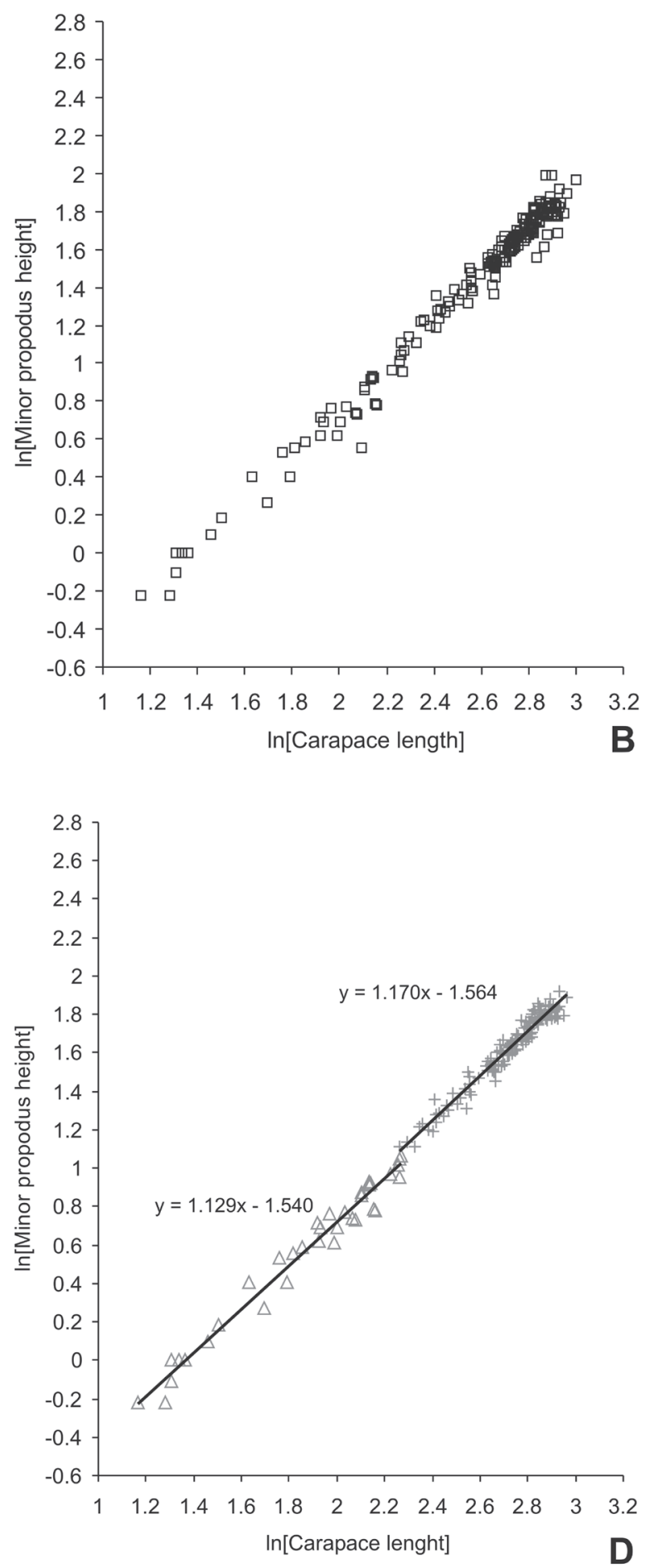

Figure 2. Aegla castro. Scatter plot representations of the $\ln$ [minor chela propodus height] vs. $\ln$ [capapace length] relationship for males (A) and females (B) prior to life stage group separation (empty squares), and for males (C) and females (D) with groups distinguished. Triangles = juveniles; crosses = adults (females and morphotype I males); circles = morphotype II adult males. Other chelae dimensions exhibited very similar patterns. 
logistic regression (Pagano and Gauvreau, 2006) on maturation condition of specimen [juvenile $=0$; adult (morphotype I only for males) =1] vs. CL data points. As sizes of morphometric maturity obtained separately for each chela variable were very similar (see Tab. 3 in the results section), the mean size estimate was considered, as suggested by Bueno and Shimizu (2009) for A. franca.

The same procedure was adopted to estimate the average size at the onset of functional maturity in males, based on the classification of adults in morphotypes I (= $0)$ and II $(=1)$. For females, immature $(=0)$ and mature individuals $(=1)$ were distinguished in accordance to the absence/ presence of reproductive traits (late ovary development or eggs attached to pleopods) as described by Bueno and Shimizu (2008). The data points included in this latter analysis were restricted to those obtained from March to June 2007 for males and from March to July 2007 and February 2008 for females when morphotype II adult males and adult females exhibiting reproductive traits, respectively, occurred in proportions higher than 20 percent in the samples. This restriction was adopted to minimize bias caused by occurrence of large individuals showing no functional maturity trait during the other months.

Sexual dimorphism associated with claw dimensions was investigated by comparing regression parameters (Student's $t$-tests) between adult females and adult morphotype I males only in accordance to Bueno and Shimizu (2009). Non-parametric Wilcoxon test for paired samples was used to verify the occurrence of the heterochelous condition in adult male (morphotypes treated separately) and female specimens. Yatescorrected goodness-of-fit chi-square test was used to investigate handedness in adult females and males (both morphotypes pooled together).

Temporal variation in proportion of ovigerous females was calculated in relation to the total number of adult females in each bimester. The temporal variation in proportion of morphotype II adult males was also considered in this analysis, so as to investigate the possible relationship between these males and reproductive events, as observed in A. franca (Bueno and Shimizu, 2009). The datasets employed in this analysis refer to the specimens collected with traps only.

All statistics analyses were based on the procedures described by Zar (1996), except otherwise noted. The
0.05 significance level was adopted for all inferential tests.

\section{RESULTS}

The number of sampled individuals totaled 542 where 314 were males (CL range: 3.10 to $23.42 \mathrm{~mm}$ ) and 228 were females (CL range: 3.20 to $20.08 \mathrm{~mm}$ ). The relationship between the two carapace measurements taken were described by a single linear function equation $\mathrm{CLR}=1.173 \mathrm{CL}+0.176\left(r^{2}=0.9990\right)$ since the relationship did not differ significantly between sexes [ANCOVA: $F=1.441 ; p=0.2306$ (comparison of slopes) and $F 0.9701 ; p=0.3251$ (comparison of elevations)].

Females showing late ovarian development $(\mathrm{n}=$ 44; CL range: 9.36 to $19.35 \mathrm{~mm}$ ) were sampled in higher proportion in March-April 2007, declined in the following bimester, became absent from samples from July2007-January 2008 and reappeared in modest proportion in February 2008 (Fig. 3). Ovigerous females ( $\mathrm{n}=9$; CL range 10.26 to $18.2 \mathrm{~mm}$ were sampled from April through August 2007, and reached a peak in proportion within the May-June period (41.7 $\%)$, defining a 5 month reproductive period extending from austral mid-autumn to late winter (Fig. 3).

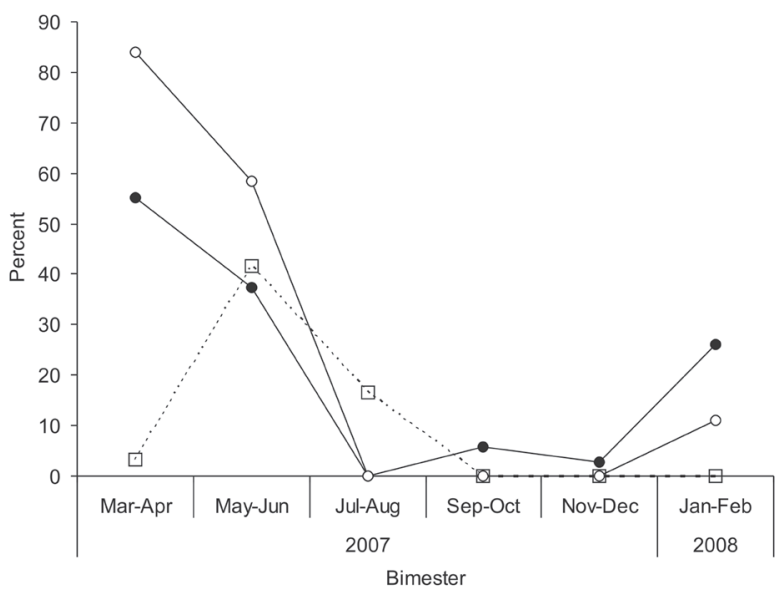

Figure 3. Aegla castro. Temporal variation in proportion of morphotype II adult males (full circles), females showing late ovarian development (empty circles) and ovigerous females (empty square and dotted line).

Allometric growth of the pair of chelae

Allometric growth analysis of chelae dimensions led to the recognition of three sequential ontogenetic phases in males (Fig. 2C). The first change in the level 
of allometry marks the transition from the juvenile phase into adulthood (puberty molt) and occurs sharply, with virtually no overlapping between the corresponding groups of data points. The second change occurs in the adult life phase and marks the transition between two sequential adult morphotypes exhibiting relative distinctiveness from each other in terms of chelae dimensions, and henceforth referred to as adult morphotype I and adult morphotype II (sensu Bueno and Shimizu, 2009). A large overlap interval between the datapoints corresponding to both adult morphotypes is observed among animals larger than $15.96 \mathrm{~mm}$ of CL $(\operatorname{lnCL}=2.77)$.

For males, the regression equation and corresponding coefficient of determination $\left(r^{2}\right)$ obtained for each recognized life stage and according to each dependent variable analyzed are shown on Tab. 1. The state of the allometric growth was positive (slope of the equation significantly larger than 1) regardless of life phase or chela dimension. A significant increase in the allometric growth coefficient was observed at puberty molt for all chela dimensions. Conversely, no variation in the allometry coefficient was detected in the transition between the two adult morphotypes and the obtained straight lines were distinguishable by elevation comparison only (Tab. 2).

For females, allometric growth analysis of $\ln$ [chelae variables] vs. In CL indicated a single change in relative growth during ontogeny, which corresponded to the puberty molt in this sex (Fig. 2D). The obtained linear regression equations and respective coefficient of determination $\left(r^{2}\right)$ are shown on Tab. 1. The state of allometry was positive for all chela dimensions. The allometric growth coefficient (b) did not differ significantly and the distinction between the juvenile and adult phases was verified by elevation comparisons only (Tab. 3).

Size at the onset of morphometric and functional maturities

The average size at the onset of morphometric maturity of males (adult morphotype I) and females, calculated as the mean of the estimates obtained from each chelae variable, were $10.91 \mathrm{~mm} \mathrm{CL}$ (12.97 $\mathrm{mm} \mathrm{CLR})$ and $10.03 \mathrm{~mm} \mathrm{CL}$ (11.94 mm CLR), respectively (Tab. 3). The average size at the onset of functional maturity is

Table 1. Linear regression (ln Chela dimension against ln Carapace length) equations and respective values of coefficient of determination $\left(r^{2}\right)$ and state of allometry in males and females of Aegla castro for each dependent variable. $\mathrm{M}=$ morphotype.

\begin{tabular}{|c|c|c|c|c|c|c|c|c|c|}
\hline \multirow{2}{*}{ Sex } & \multirow{2}{*}{ Claw } & \multirow{2}{*}{ Dependent variable } & \multirow{2}{*}{ Life stage } & \multicolumn{3}{|c|}{ Linear regression } & \multicolumn{2}{|c|}{$t$-test $\left(H_{0}:\right.$ slope $\left.=1\right)$} & \multirow{2}{*}{ State of allometry } \\
\hline & & & & $\mathrm{n}$ & equation & $r^{2}$ & $t$ & $p$ & \\
\hline \multirow{12}{*}{ Males } & \multirow{6}{*}{ Major } & \multirow[t]{3}{*}{ Propodus length } & Juveniles & 44 & $y=1.148 x-0.834$ & 0.979 & 5.794 & $<0.05$ & Positive \\
\hline & & & MI adults & 187 & $y=1.381 x-1.410$ & 0.971 & 21.872 & $<0.05$ & Positive \\
\hline & & & MII adults & 25 & $y=1.306 x-1.015$ & 0.796 & 2.224 & $<0.05$ & Positive \\
\hline & & \multirow[t]{3}{*}{ Propodus height } & Juveniles & 42 & $y=1.368 x-1.895$ & 0.971 & 9.839 & $<0.05$ & Positive \\
\hline & & & MI adults & 189 & $y=1.503 x-2.213$ & 0.963 & 23.276 & $<0.05$ & Positive \\
\hline & & & MII adults & 22 & $y=1.459 x-1.869$ & 0.871 & 3.663 & $<0.05$ & Positive \\
\hline & \multirow{6}{*}{ Minor } & \multirow[t]{3}{*}{ Propodus length } & Juveniles & 39 & $y=1.135 x-0.80$ & 0.973 & 4.356 & $<0.05$ & Positive \\
\hline & & & MI adults & 178 & $y=1.313 x-1.297$ & 0.968 & 17.529 & $<0.05$ & Positive \\
\hline & & & MII adults & 22 & $y=1.391 x-1.359$ & 0.853 & 3.039 & $<0.05$ & Positive \\
\hline & & \multirow[t]{3}{*}{ Propodus height } & Juveniles & 42 & $y=1.302 x-1.821$ & 0.968 & 8.036 & $<0.05$ & Positive \\
\hline & & & MI adults & 187 & $y=1.474 x-2.280$ & 0.952 & 19.66 & $<0.05$ & Positive \\
\hline & & & MII adults & 19 & $y=1.334 x-1.657$ & 0.845 & 2.412 & $<0.05$ & Positive \\
\hline \multirow{8}{*}{ Females } & \multirow{4}{*}{ Major } & \multirow[t]{2}{*}{ Propodus length } & Juveniles & 44 & $y=1.080 x-0.718$ & 0.975 & 3.06 & $<0.05$ & Positive \\
\hline & & & Adults & 137 & $y=1.130 x-0.798$ & 0.966 & 7.232 & $<0.05$ & Positive \\
\hline & & \multirow[t]{2}{*}{ Propodus height } & Juveniles & 41 & $y=1.271 x-1.715$ & 0.983 & 10.432 & $<0.05$ & Positive \\
\hline & & & Adults & 136 & $y=1.216 x-1.543$ & 0.959 & 9.974 & $<0.05$ & Positive \\
\hline & \multirow{4}{*}{ Minor } & \multirow[t]{2}{*}{ Propodus length } & Juveniles & 41 & $y=1.076 x-0.770$ & 0.96 & 2.184 & $<0.05$ & Positive \\
\hline & & & Adults & 134 & $y=1.099 x-0.783$ & 0.963 & 5.36 & $<0.05$ & Positive \\
\hline & & \multirow[t]{2}{*}{ Propodus height } & Juveniles & 35 & $y=1.129 x-1.539$ & 0.972 & 3.926 & $<0.05$ & Positive \\
\hline & & & Adults & 130 & $y=1.170 x-1.564$ & 0.955 & 7.635 & $<0.05$ & Positive \\
\hline
\end{tabular}


Table 2. Comparison of linear regression parameters between life stages of Aegla castro.

\begin{tabular}{|c|c|c|c|c|c|}
\hline \multirow{2}{*}{ Sex } & \multirow{2}{*}{ Life Stages } & \multirow{2}{*}{ Claw } & \multirow{2}{*}{ Dependent variables } & \multicolumn{2}{|c|}{ Comparison } \\
\hline & & & & Slopes & Elevations \\
\hline \multirow{8}{*}{ Males } & \multirow{4}{*}{$\begin{array}{l}\text { Juveniles and } \\
\text { morphotype I adults }\end{array}$} & \multirow{2}{*}{ Major } & Propodus length & $t=8.50 ; p<0.05$ & - \\
\hline & & & Propodus height & $t=3.74 ; p<0.05$ & - \\
\hline & & \multirow{2}{*}{ Minor } & Propodus length & $t=5.95 ; p<0.05$ & - \\
\hline & & & Propodus height & $t=4.45 ; p<0.05$ & - \\
\hline & \multirow{4}{*}{$\begin{array}{l}\text { Morphotype I } \\
\text { and II adults }\end{array}$} & \multirow{2}{*}{ Major } & Propodus length & $t=0.78 ; p>0.05$ & $t=19.55 ; p<0.05$ \\
\hline & & & Propodus height & $t=0.39 ; p>0.05$ & $t=19.44 ; p<0.05$ \\
\hline & & \multirow{2}{*}{ Minor } & Propodus length & $t=0.79 ; p>0.05$ & $t=18.21 ; p<0.05$ \\
\hline & & & Propodus height & $t=1.09 ; p>0.05$ & $t=16.46 ; p<0.05$ \\
\hline \multirow{4}{*}{ Females } & \multirow{4}{*}{$\begin{array}{l}\text { Juveniles } \\
\text { and adults }\end{array}$} & \multirow{2}{*}{ Major } & Propodus length & $t=1.55 ; p>0.05$ & $t=3.22 ; p<0.05$ \\
\hline & & & Propodus height & $t=1.76 ; p>0.05$ & $t=2.60 ; p<0.05$ \\
\hline & & \multirow{2}{*}{ Minor } & Propodus length & $t=0.68 ; p>0.05$ & $t=2.60 ; p<0.05$ \\
\hline & & & Propodus height & $t=1.17 ; \mathrm{p}>0.05$ & $t=4.05 ; p<0.05$ \\
\hline
\end{tabular}

Table 3. Size at onset of morphometric and functional maturities males and females of Aegla castro. Parameters of the logistic function fitted in each analysis are included.

\begin{tabular}{|c|c|c|c|c|c|c|c|}
\hline \multirow[t]{2}{*}{ Sex } & \multirow[t]{2}{*}{ Maturity } & \multicolumn{2}{|c|}{ Criteria for separating groups } & \multicolumn{2}{|c|}{ Logistic function parameters } & \multirow[t]{2}{*}{ CL50 (mm) } & \multirow[t]{2}{*}{ CLR50 (mm) } \\
\hline & & Claw & Variable & $\mathrm{b}$ & a & & \\
\hline \multirow{10}{*}{ Males } & \multirow{5}{*}{ Morphometric } & \multirow{2}{*}{ Major } & Propodus height & 4.71 & -51.48 & 10.92 & 12.99 \\
\hline & & & Propodus length & 78.61 & -864.71 & 11.00 & 13.08 \\
\hline & & \multirow{2}{*}{ Minor } & Propodus height & 44.55 & -495.87 & 11.11 & 13.21 \\
\hline & & & Propodus length & 46.61 & -493.44 & 10.59 & 12.60 \\
\hline & & - & Mean & & & 10.91 & 12.97 \\
\hline & \multirow{5}{*}{ Functional } & \multirow{2}{*}{ Major } & Propodus height & 1.89 & -31.60 & 16.70 & 19.78 \\
\hline & & & Propodus length & 1.57 & -26.73 & 17.00 & 20.14 \\
\hline & & \multirow{2}{*}{ Minor } & Propodus height & 0.80 & -14.32 & 17.86 & 21.16 \\
\hline & & & Propodus length & 1.07 & -18.11 & 16.94 & 20.07 \\
\hline & & - & Mean & & & 17.12 & 20.26 \\
\hline \multirow{6}{*}{ Females } & \multirow{5}{*}{ Morphometric } & \multirow{2}{*}{ Major } & Propodus height & 5.96 & -59.96 & 10.06 & 11.98 \\
\hline & & & Propodus length & 72.49 & -743.75 & 10.25 & 12.20 \\
\hline & & \multirow{2}{*}{ Minor } & Propodus height & 14.08 & -136.87 & 9.72 & 11.58 \\
\hline & & & Propodus length & 69.19 & -696.73 & 10.07 & 11.99 \\
\hline & & - & Mean & & & 10.03 & 11.94 \\
\hline & Functional & - & Reproductive traits & 0.38 & -4.84 & 12.59 & 14.94 \\
\hline
\end{tabular}

achieved later in life, being $17.12 \mathrm{~mm}$ CL $(20.26 \mathrm{~mm}$ CLR) in males and $12.59 \mathrm{~mm} \mathrm{CL}$ (14.94 mm CLR) for females (Tab. 3).

The temporal sequence of $\ln$ [chelae variables] vs. In CL (Fig. 4) shows that the proportion of morphotype II adult males was at its highest within the March-April 2007 period, then declined in the following months until they were no longer sampled within the July-August 2007 period and were replaced by the morphotype I adult males belonging to a 1-year younger new cohort. From September 2007 onwards, the transition of these latter males into morphotype II occurred gradually. The temporal variation of proportions of morphotype II adult males and adult females showing developing reproductive traits matched closely (Fig. 3 ).

\section{Heterochely and handedness}

Adult males (both morphotypes) and females of $A$. castro are heterochelous ( $\rho<0.05$ in all cases) with handedness preponderance of the left chela as being the most robust of the pair (males: $72.95 \% ; \chi^{2}=43.60$, $\rho<0.05$; females: $80.47 \%$; $\chi^{2}=47.53, \rho<0.05$ ). 


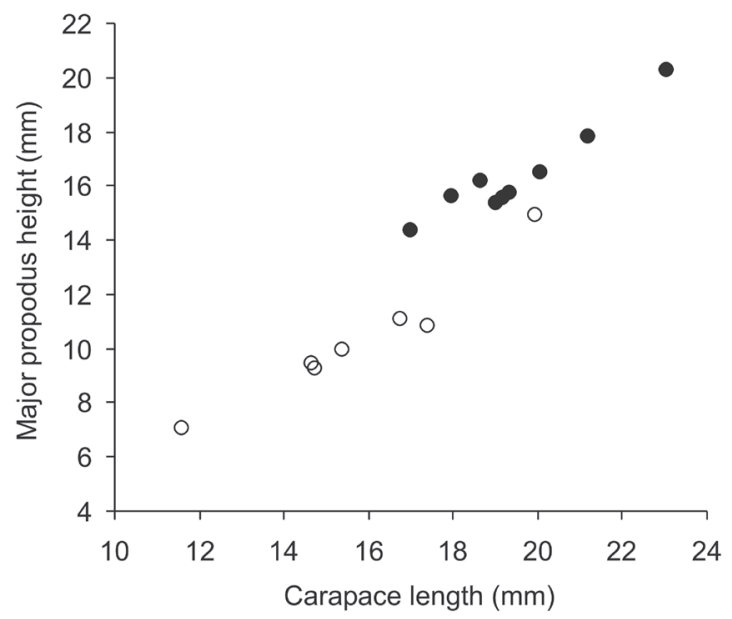

May-June 2007

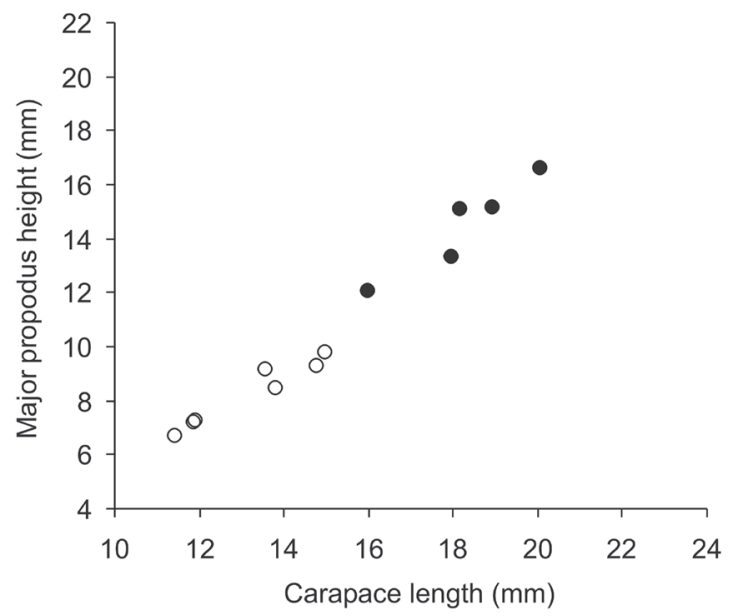

July-August 2007

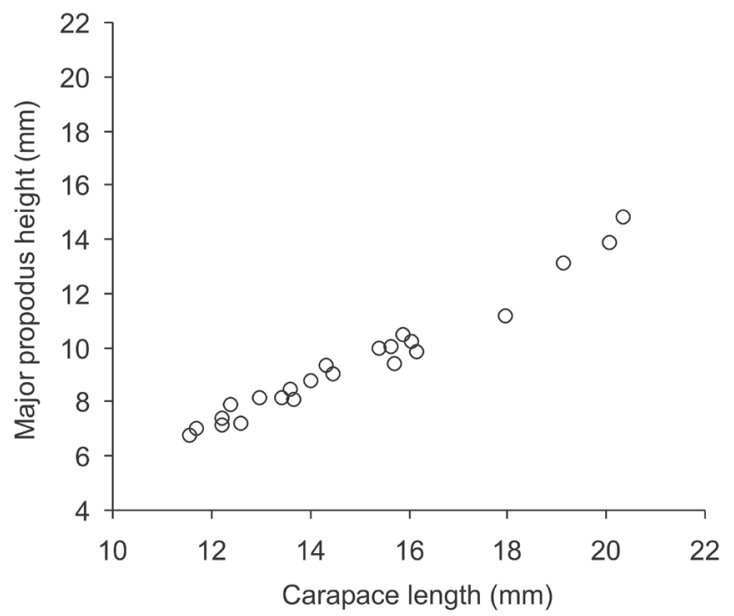

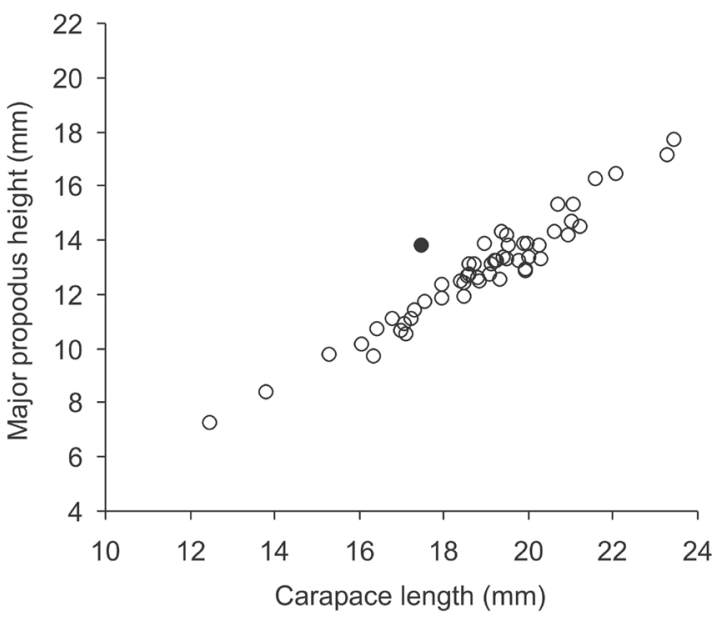

November-December 2007

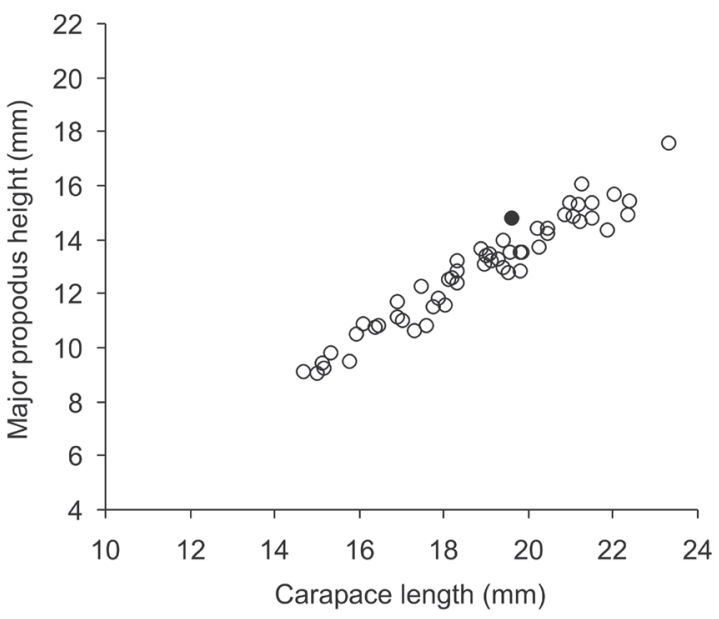

January-February 2008

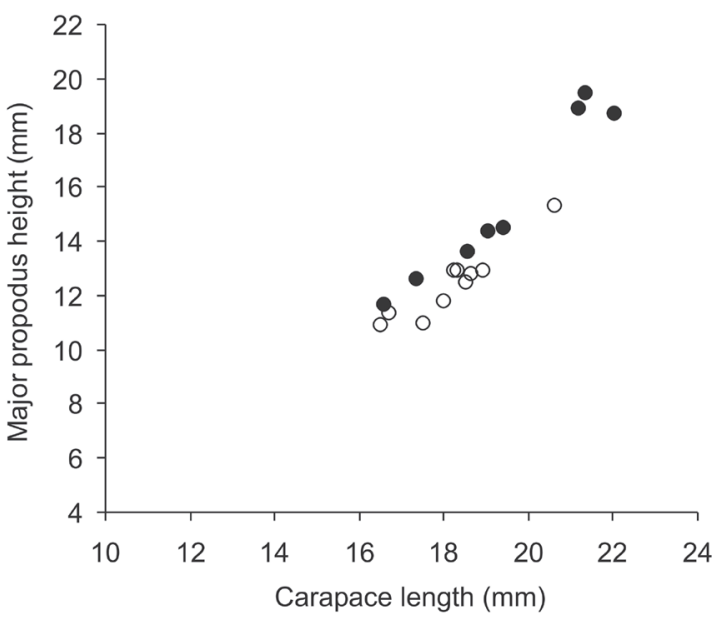

Figure 4. Aegla castro. Temporal sequence of major chelae propodus height $v$ s. carapace length scatterplots of adult males. Empty circles $=$ morphotype I; full circles $=$ morphotype II. Other chelae dimensions exhibited very similar patterns. 


\section{Sexual dimorphism}

The allometric growth coefficient (b) of the $\ln$ [chelae variable] vs. $\operatorname{lnCL}$ relationship differed between adult females and adult morphotype I males $(t=11.60$; $\rho$ $<0.05$ ) indicating that dimensions of the pair of chelae are sexually dimorphic traits (Fig. 5). Males exhibit larger and more robust chelipeds when compared to those of similar-size females after puberty molt.

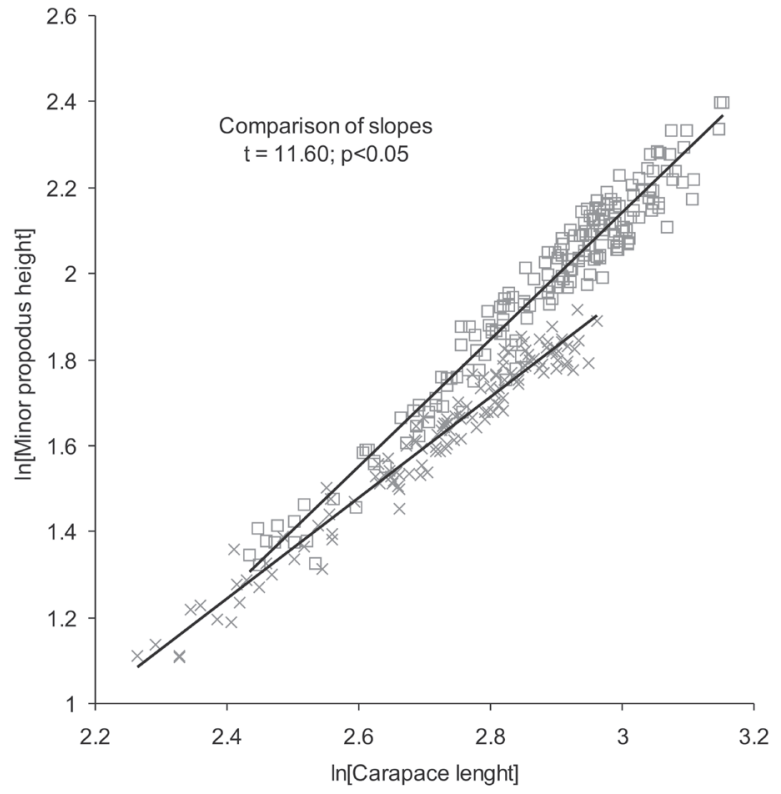

Figure 5. Aegla castro. Sexual dimorphism in minor chela propodus height. Squares $=$ morphotype I adult males; $\mathrm{X}=$ adult females. Corresponding regression equations in Figure 1 ( $\mathrm{C}$ and D). Other chelae dimensions exhibited very similar patterns.

\section{Discussion}

Aegla is typically heterochelous, with handedness of the more robust chela predominantly skewed to the left side of the pair (Schmitt, 1942; Bahamonde and López, 1961; López, 1965; Rodrigues and Hebling, 1978; Viau et al., 2006; Bueno and Shimizu, 2009; Oliveira and Santos, 2011). In these freshwater anomurans, heterochely is equally observed in the population regardless of sex, except for a single case of homochely reported in males and females of Aegla leptodactyla Buckup and Rossi, 1977 (Noro and Buckup, 2003). The differential relative growth of the chelae, however, is a sex-dependent morphological attribute as both major and minor chelae are larger and heavier in males than they are in females of similar size, thus characterizing a conspicuous sexually dimorphic trait in Aegla (Bueno and Shimizu, 2009).
In heterochelous decapods, each chelae may be used in different ways when it comes to manipulating food, but the use of the smaller (or minor) chela is also associated with grooming behavior, while the larger (or major) chela plays an important role in agonistic confrontations and reproductive behavior (Mariappan et al., 2000). In Aegla uruguayana Schmitt, 1942, for example, Viau et al. (2006) reported that sexually functional males use the major claw to defend receptive females from other males. However, both chelipeds may participate in specific reproductive tasks. For instance, adult males of Aegla platensis Schmitt, 1942 employ both major and minor claws to grasp, lift and rotate the body of the receptive female so as to properly position her in relation to his body at the beginning of the copulatory phase (Almerão et al., 2010).

In allometric growth analyses conducted with male specimens, meristic data obtained from the propodus of the chelipeds have been extensively selected as dependent variables. Although pleon dimensions have frequently been used as dependent variable (Colpo et al., 2005; Viau et al., 2006; Oliveira and Santos, 2011; Trevisan and Santos, 2012; Copatti et al., 2015) in similar studies regarding female aeglids, Bueno and Shimizu (2009) have shown that the use of chelae dimensions as dependent variables in allometric growth analysis can be equally informative either in males or females and can provide very consistent and precise results, as long as bivariate dataset (selected dependent variable $v s$. independent variable) are grouped according to major and minor chelae criterion. This procedure is recommended so as to avoid the introduction of possible biased data whenever a predominantly-sided handedness - while still exhibiting proportion of individuals with reversed handedness - is clearly detected in a heterochelous population should the left-and-right chelae criterion be chosen instead (Bueno and Shimizu, 2009). In the present work, all analyzed chela dimensions allowed adequate separation of life stage data into groups for both males and females of $A$. castro (Tabs. 1,3). Results on the average size at the onset of the morphometric maturity (= puberty molt) obtained for each of the four dependent variable were very close, suggesting the existence of coherent biological meaning in the estimates obtained for each sex separately. 
Since maturity is size related, the ratio between the size at the onset of maturity and the asymptotic size ( $L_{\infty}$ of the von Bertallanffy growth equation) tends to be constant, and is defined as the relative size at the onset of maturity, or RSOM (Charnov, 1990). The validity of this assumption has been demonstrated in pandalid shrimps and grapsid crabs (Charnov, 1990; Conde and Diáz, 1992). Tab. 4 is an update of Tab. 3 originally provided by Oliveira and Santos (2011) and includes the currently available data on size at onset of morphometric maturity and its proportion in relation to the size of the largest sampled individual of Aegla species. Although the absolute sizes vary considerably among species, the range of variation in proportion is fairly narrow (0.38-0.60), indicating that aeglids tend to attain morphometric maturity by the time they are approximately half as large as the maximum size they reach. The values of this proportion seem to not depend on sex, species or environmental conditions (study sites with latitudes varying from $20^{\circ} 18^{\prime}$ to $\left.34^{\circ} 14^{\prime}\right)$. This is expected since this proportion is an approximation of the RSOM. The close values of proportion between sexes particularly suggest that the trend of males attaining morphometric maturity at a larger size than females, commonly verified in aeglid species, results from the species-specific growth pattern each sex presents. Conversely, the time at which the size at onset of morphometric maturity is attained may vary among species. In accordance to the somatic growth pattern data compiled by Silva-Gonçalves et al. (2009), Cohen et al. (2011) and Trevisan and Santos (2011), complemented by results obtained by Chiquetto-Machado et al. (2016), species found in lower latitude locations $\left(<25^{\circ}\right)$ tend to grow more slowly and, thus, are expected to take longer to attain morphometric maturity than those found in higher latitude regions.

One remarkable biological feature associated with sexual maturity in A. castro is the recognition of two adult male morphotypes in the population, as similarly reported by Bueno and Shimizu (2009) in A. franca. In both species, morphotype I and II (Bueno and Shimizu, 2009) are sequential phases in the adult male ontogenetic development. Morphotype II shows heavier and larger pair of chelae than the preceding morphotype I, as demonstrated by significant change in the allometric growth coefficient during adulthood (Tab. 1).
Similarly to what has been observed in A. franca, the gradual transition from morphotype I to the sexually functional morphotype II in the population occurs as the mating period gets closer (Bueno and Shimizu, 2009; this paper). The temporal variation of proportions of morphotype II males and females showing late ovarian development are synchronous in both species (Fig. 3, this paper; Fig. 7 in Bueno and Shimizu, 2009). The combination of the pieces of information above reinforces the relationship between these males and reproductive activity, as well as the adequacy of the use of data from the morphotypes for estimating the size at the onset of functional maturity as proposed by Bueno and Shimizu (2009).

Also included on Tab. 4 are the currently available data on size at onset of functional maturity and its proportion in relation to the size of the largest male and/or female of Aegla species. As in the case of the morphometric maturity, the absolute values varied more widely than the proportions in relation to the largest size among species. The relative values of $A$. castro, A. franca, Aegla parana Schmitt, 1942 and Aegla schmitti Hobbs III, 1978 (data for the latter two species are available for females only) are very close within each sex, and tend to be higher in males. In the case of $A$. uruguayana, the proportions are similar between sexes and are both lower when compared to that found in the other aforementioned species. Although the current dataset is limited, these differences might be attributed to distinct criteria adopted for separating mature and immature individuals for the analyses. In the case of A. franca and $A$. castro, the criteria differed between males (size at which $50 \%$ of adults were morphotype II) and females (size at which $50 \%$ of individuals showed reproductive traits). As for A. uruguayana, the smallest individual showing reproductive traits was considered for males (spermatozoa in the vas deferens) and females (eggs attached to the pleopods). While the adoption of criteria of similar nature (reproductive traits) led to closer estimates between sexes of this species, the smallest size criterion might have caused the size at onset of functional maturity to be underestimated when compared to values obtained based on the size at which $50 \%$ of individuals are functionally mature. This latter proposition is reinforced by the low proportion (similar to that of A. uruguayana) obtained for Aegla manuinflata Bond-Buckup and Santos, 2009 (in Santos 
Table 4. Carapace length (rostrum included except where noted) at the onset of morphological and functional maturity and correspondent proportion in relation to the largest sample size of Aegla species. Species are ordered in accordance to study site latitudes (low to high). S.d. = standard deviation. 1 - Bueno and Shimizu (2009); 2 - Present study; 3 - Oliveira and Santos (2011); 4 - Copatti et al. (2015); 5 - Colpo et al. (2005); 6 - Trevisan and Santos (2012) and Santos et al. (2009); 7 - Viau et al. (2006); 8 Chiquetto-Machado et al. (2016); 9- Grabowski et al., 2013. * - Values recalculated after adoption of dataset restriction as described in the Material and methods section.

\begin{tabular}{|c|c|c|c|c|c|c|c|}
\hline \multirow{2}{*}{ Maturity } & \multirow{2}{*}{ Species } & \multicolumn{2}{|c|}{ Size at the onset of maturity $(\mathrm{mm})$} & \multicolumn{2}{|c|}{ Largest sampled size (mm) } & \multicolumn{2}{|c|}{ Proportion of the largest size } \\
\hline & & Males & Females & Males & Females & Males & Females \\
\hline \multirow{13}{*}{ Morphometric } & A. franca ${ }^{1}$ & $12.15(\mathrm{CL})$ & $10.93(\mathrm{CL})$ & $21.97(\mathrm{CL})$ & $18.83(\mathrm{CL})$ & 0.55 & 0.58 \\
\hline & & 14.40 & 11.81 & 25.62 & 20.65 & 0.56 & 0.57 \\
\hline & A. castro $^{2}$ & $10.91(\mathrm{CL})$ & $10.03(\mathrm{CL})$ & $23.42(\mathrm{CL})$ & $18.20(\mathrm{CL})$ & 0.47 & 0.55 \\
\hline & & 12.97 & 11.94 & 27.65 & 21.52 & 0.47 & 0.55 \\
\hline & A. platensis ${ }^{3}$ & 19.15 & 16.5 & 31.75 & 27.92 & 0.60 & 0.59 \\
\hline & A. platensis ${ }^{4}$ & 14.21 & 11.59 & 32.00 & 23.77 & 0.44 & 0.49 \\
\hline & A. grisella ${ }^{4}$ & 14.08 & 13.75 & 30.1 & 22.9 & 0.47 & 0.60 \\
\hline & A. ludwigi ${ }^{4}$ & 13.13 & 13.74 & 33.4 & 26.09 & 0.40 & 0.53 \\
\hline & A. longirostri ${ }^{5}$ & 13.7 & 10.7 & 23.8 & 18.9 & 0.58 & 0.57 \\
\hline & A. manuinflata ${ }^{6}$ & 13.6 & 10.84 & 27.9 & 24.12 & 0.49 & 0.45 \\
\hline & A. uruguayana & 15.4 & 11.5 & 34.7 & 30.1 & 0.44 & 0.38 \\
\hline & Mean (CLR) & 14.52 & 12.49 & 29.66 & 24.00 & 0.49 & 0.53 \\
\hline & S.d. & 1.88 & 1.86 & 3.66 & 3.56 & 0.07 & 0.07 \\
\hline \multirow{11}{*}{ Functional } & A. franca $^{1}$ & $16.44(\mathrm{CL})^{*}$ & $12.75(\mathrm{CL})$ & $21.97(\mathrm{CL})$ & $18.83(\mathrm{CL})$ & 0.75 & 0.68 \\
\hline & & $19.30^{*}$ & 13.84 & 25.62 & 20.65 & 0.75 & 0.67 \\
\hline & A. castro ${ }^{2}$ & $17.12(\mathrm{CL})$ & $12.59(\mathrm{CL})$ & $23.42(\mathrm{CL})$ & $18.20(\mathrm{CL})$ & 0.73 & 0.69 \\
\hline & & 20.26 & 14.94 & 27.65 & 21.52 & 0.73 & 0.69 \\
\hline & A. schmitti ${ }^{8}$ & & 12.92 & 27.83 & 20.94 & & 0.62 \\
\hline & & & 15.59 & 33.31 & 25.10 & & 0.62 \\
\hline & A.parana9 & & 17.40 & 29.80 & 27.00 & & 0.64 \\
\hline & A. manuinflata ${ }^{6}$ & & 12.34 & & 24.12 & & 0.51 \\
\hline & A. uruguayana ${ }^{7}$ & 18.7 & 15.6 & 34.7 & 30.1 & 0.54 & 0.52 \\
\hline & Mean (CLR) & 19.43 & 14.80 & 29.32 & 24.09 & 0.68 & 0.63 \\
\hline & S.d. & 0.84 & 0.89 & 4.77 & 5.22 & 0.12 & 0.12 \\
\hline
\end{tabular}

et al., 2009) for which the size at onset of functional maturation was also estimated based on the size of the smallest ovigerous female.

Starting with the hatching of juveniles by JulyAugust, when proportion of ovigerous females decreased after the peak (Fig. 3), A.castro attains fully functional maturity and engage in mating activities almost two years later (March-April) by the time the adults are 20-21 months of age. This pattern is coherent with those observed in $A$. franca, $A$. strinatii Türkay, 1972, A. paulensis Schmitt, 1942 and A. schmitti, species from low latitude locations which become functionally mature at 19-21 months of age (Bueno and Shimizu, 2008; Rocha et al., 2010; Cohen et al., 2011; Chiquetto-Machado et al., 2016). As expected from their faster individual growth, species from higher latitude locations attain functional maturity earlier in their respective life cycle, as reported for A. platensis (12.6-15.6 months) and Aegla longirostri Bond-Buckup and Buckup, 1994 (8 and 12 months) (Bueno and Bond-Buckup, 2000; Bueno et al., 2000; Colpo et al., 2005; Silva-Castiglioni et al., 2006).

In the present study, the population of $A$. castro from Itatinga shows marked seasonal reproductive period lasting for 5 months (April-August), which is in accordance to the pattern of latitudinal variation of breeding period duration as proposed by Bueno and Shimizu (2008) and supported by similar findings from works published later on for other aeglid species (Rocha et al., 2010; Cohen et al., 2011; Grabowski et al., 2013; Bueno et al., 2014; Chiquetto-Machado et al., 2016). This result, however, is 2.5 times longer than 
the 2 months period (May-June) previously reported for the same A castro population studied previously by Fransozo et al. (2003), but is closer to that verified in the population (6 months) from Ponta Grossa, State of Paraná (Swiech-Ayoub and Masunari, 2001b). By examining the available data from these three studies, those of Fransozo et al. (2003) showed comparatively lower proportions of larger individuals than samples from the other two studies, which might have been caused by the lower number of sampled ovigerous females resulting in the underestimation of the duration of reproductive period.

\section{ACKNOWLEDGEMENTS}

This paper is dedicated to Dr. Nilton Hebling in recognition of his works on aeglids from the state of São Paulo. We would like to express our gratitude to Dr. Adilson Fransozo and Dr. Maria Lúcia NegreiroFransozo for kindly inviting us to contribute to the Nauplius special publication dedicated to Dr. Nilton Hebling. Thanks also to Ana Teresa Bueno for reviewing the English text.

\section{References}

Almerão, M.; Bond-Buckup, G. and Mendonça Jr., M.S. 2010. Mating behavior of Aegla platensis (Crustacea, Anomura, Aeglidae) under laboratory conditions. Journal of Ethology, 28: 87-94.

Bahamonde, N. and López, M.T. 1961. Estudios biologicos em la poblacion de Aegla laevis laevis (Latreille) de el Monte (Crustacea, Decapoda, Anomura). Investigaciones Zoologicas Chilenas, 7: 19-58.

Bond-Buckup, G. and Buckup, L. 1994. A família Aeglidae (Crustacea, Decapoda, Anomura). Arquivos de Zoologia, 32(4): 159-346.

Bond-Buckup, G.; Jara, C.G.; Pérez-Losada, M.; Buckup, L. and Crandall, K.A. 2008. Global diversity of crabs (Aeglidae: Anomura: Decapoda) in freshwater. Hydrobiologia, 595: 267-273.

Buckup, L. and Rossi, A. 1977. O gênero Aegla no Rio Grande do Sul, Brasil (Crustacea, Decapoda, Anomura, Aeglidae). Revista Brasileira de Biologia, 37(4): 879-892.

Bueno, A.A.P. and Bond-Buckup, G. 2000. Dinâmica populacional de Aegla platensis Schmitt (Crustacea, Decapoda, Aeglidae). Revista Brasileira de Zoologia, 17(1): 43-49.

Bueno, A.A.P.; Bond-Buckup, G. and Buckup, L. 2000. Crescimento de Aegla platensis Schmitt em ambiente natural (Crustacea, Decapoda, Aeglidae). Revista Brasileira de Zoologia, 17(1): 51-60.

Bueno, S.L.S. and Shimizu, R.M. 2008. Reproductive biology and functional maturity in females of Aegla franca (Decapoda: Anomura: Aeglidae). Journal of Crustacean Biology, 28: $652-662$.
Bueno, S.L.S. and Shimizu, R.M. 2009. Allometric growth, sexual maturity, and adult male chelae dimorphism in Aegla franca (Decapoda: Anomura: Aeglidae). Journal of Crustacean Biology, 29(3): 317-328.

Bueno, S.L.S.; Shimizu, R.M. and Rocha, S.S. 2007. Estimating the population size of Aegla franca (Decapoda, Anomura, Aeglidae) by mark-recapture technique from an isolated section of Barro Preto stream, county of Claraval, state of Minas Gerais, southeastern Brazil. Journal of Crustacean Biology, 27(4): 553-559.

Bueno, S.L.S.; Takano, B.F.; Cohen, P.A.; Moraes, J.C.B.; Chiquetto-Machado, P.I.; Vieira, L.C.M. and Shimizu, R.M. 2014. Fluctuations in the population size of the highly endemic Aegla perobae (Decapoda: Anomura: Aeglidae) caused by a disturbance event. Journal of Crustacean Biology, 34(2): 165-173.

Charnov, E.L. 1990. Relative size at the onset of maturity (RSOM) is an interesting number in crustacean growth (Decapoda, Pandalidae). Crustaceana, 59(1): 108-109.

Chiquetto-Machado, P.I.; Vieira, L.C.M.; Shimizu, R.M. and Bueno, S.L.S. 2016. Life cycle of the freshwater anomuran Aegla schmitti Hobbs, 1978 (Decapoda: Anomura: Aeglidae) from southeastern Brazil. Journal of Crustacean Biology, 36(1): 39-45.

Cohen, F.P.A.; Takano, B.F.; Shimizu, R.M. and Bueno, S.L.S. 2011. Life cycle and population structure of Aegla paulensis (Decapoda: Anomura: Aeglidae). Journal of Crustacean Biology, 31(3): 389-395.

Colpo, K.D.; Ribeiro, L.O. and Santos, S. 2005. Population biology of the freshwater anomuran Aegla longirostri (Aeglidae) from south Brazilian streams. Journal of Crustacean Biology, 25: 495-499.

Conde, J.E. and Diáz, H. 1992. Variations in intraspecific relative size at the onset of maturity (RSOM) in Aratus pisonii ( $\mathrm{H}$. Milne Edwards, 1837) (Decapoda, Brachyura, Grapsidae). Crustaceana, 62(2): 214-216.

Copatti, C.E.; Machado, J.V. and Trevisan, A. 2015. Morphological variation in the sexual maturity of three sympatric aeglids in a river in southern Brazil. Journal of Crustacean Biology, 35(1): 59-67.

Dana, J.D. 1852. Crustacea. Part 1. In, United States Exploring Expedition during the Years 1838, 1839, 1840, 1841, 1842, Under the Command of Charles Wilkes, U.S.N., S.1. Vol. 13: 475-478.

Feldmann, R.M. 1984. Haumuriaegla glaessneri n. gen. and sp. (Decapoda; Anomura; Aeglidae) from Haumurian (late Cretaceous) rocks near Cheviot, New Zealand. New Zealand Journal of Geology and Geophysics, 27: 379-385.

Feldmann, R.M.; Vega, F.J.; Applegate, S.P. and Bishop, G.A. 1998. Early Cretaceous arthropods from the Tlayúa formation at Tepexi de Rodríguez, Puebla, México. Journal of Paleontology, 72(1): 79-90.

Fernandes, C.S.; Bueno, S.L.S. and Bichuette, M.E. 2013. Distribution of cave-dwelling Aegla spp. (Decapoda: Anomura: Aeglidae) from the Alto Ribeira karstic area in southeastern Brazil based on geomorphological evidence. Journal of Crustacean Biology, 33(4):567-575.

Fransozo, A.; Costa, R.C.; Reigada, A.L.D. and Nakagaki, J.M. 2003. Population structure of Aegla castro Schmitt, 1942 
(Crustacea, Anomura, Aeglidae) from Itatinga (SP), Brazil. Acta Limnologica Brasiliensia, 15(2): 13-20.

Grabowski, R.C.; Santos, S. and Castilho, A.L. 2013. Reproductive eecology and size of sexual maturity in the anomuran crab Aegla parana (Decapoda: Aeglidae). Journal of Crustacean Biology, 33(3): 332-338.

Hammer, Ø.; Harper, D.A.T. and Ryan, P.D. 2001. PAST: Paleontological Statistics Software Package for Education and Data Analysis. Paleontologia Electronica, 4(1): 9pp. http://palaeo-electronica.org/2001_1/past/issue1_01.htm

Hartnoll, R.G. 1978. The determination of relative growth in Crustacea. Crustaceana, 34(3): 281-293.

Hartnoll, R.G. 1982. Growth. P. 111-196. In: L.G. Abele (ed), The biology of Crustacea. Embryology, morphology, and genetics, Vol. 2. New York, Academic Press.

Hartnoll, R. G. 1985. Growth, sexual maturity and reproductive output. p. 101-128. In: A.M. Wenner (ed), Factors in adult growth. Crustacean Issues, Vol. 3. Rotterdam, A.A. Balkema.

Hobbs III, H.H. 1978. A new species of the endemic South American genus Aegla from Paraná, Brazil (Crustacea, Anomura, Aeglidae). Proceedings of the Biological Society of Washington, 91: 982-988.

Leach, W.E. 1820. Galatéadées. p. 49-56. In: F.G. Levrault (ed), Dictionnaire des Sciences Naturalles 18. Paris.

Legendre, P. and Legendre, L. 1998. Numerical Ecology. Amsterdam, Elsevier, 853p.

López, M.T. 1965. Estudios biológicos em Aegla oderbrechtti paulensis Schmitt (Crustacea, Decapoda, Anomura). Boletim da Faculdade de Filosofia, Ciências e Letras da Universidade de São Paulo, série Zoologia, 25: 301-314.

López-Greco, L.S. and Rodríguez, E.M. 1999. Size at the onset maturity in Chasmagnathus granulatus Dana, 1851 (Grapsidae, Sesarminae): a critical overall view about the usual criteria for its determination. p. 675-689. In: F.R. Schram and J.C. von Vaupel Klein (eds), Crustaceans and the Biodiversity Crisis: Proceedings of the Fourth International Crustaceans Congress, Vol. 1. Leiden, Brill.

Mariappan, P.; Balasundaram, C. and Schmitz, B. 2000. Decapod crustacean chelipeds: an overview. Journal of Biosciences, 25 : 301-313.

Martin, J.W. and Abele, L.G. 1988. External morphology of the genus Aegla (Crustacea: Anomura: Aeglidae). Smithsonian Contributions to Zoology, 453: 1-46.

Martínez-Mayén, M.; Róman-Contreras, R.; Rocha-Ramírez, A. and Chazaro-Olvera, S. 2000. Relative growth of Atya margaritacea (Milne-Edwards, 1864) (Decapoda, Atyidae) from the southern Pacific coast of Mexico. Crustaceana, 73(5): 525-534.

Mclaughlin, P.A.; Lemaitre, R. and Crandall, K.A. 2010. Annotated checklist of anomurans decapod crustaceans of the world (exclusive of the Kiwaoidea and families Chirostylidae and Galatheidae of the Galatheoidea). Part III - Aegloidea. The Raffles Bulletin of Zoology, Supplement 23: 131-137.

Noro, C. and Buckup, L. 2003. O crescimento de Aegla leptodactyla Buckup and Rossi (Crustacea, Anomura, Aeglidae). Revista Brasileira de Zoologia, 20(2): 191-198.

Oliveira, D. and Santos, S. 2011. Maturidade sexual morfológica de Aegla platensis (Crustacea, Decapoda, Anomura) no Lajeado Bonito, norte do estado do Rio Grande do Sul, Brasil. Iheringia, Série Zoologia, 101(1-2): 127-130.
Oyanedel, A.; Valdovinos, C.; Sandoval, N.; Moya, C.; Kiessling, G.; Salvo, J. and Olmos, V. 2011. The southermost freshwater anomurans of the world: Geographic distribution and new records of Patagonian aeglids (Decapoda: Aeglidae). Journal of Crustacean Biology, 31(3): 396-400.

Pagano, M. and Gauvreau, K. 2006. Princípios de Bioestatística. São Paulo, Thomson.

Rocha, S.S.; Shimizu, R.M. and Bueno, S.L.S. 2010. Reproductive biology in females of Aegla strinatii (Decapoda: Anomura: Aeglidae). Journal of Crustacean Biology, 30(4): 589-596.

Rodrigues, W. and Hebling, N.J. 1978. Estudos biológicos em Aegla perobae Hebling and Rodrigues, 1977 (Decapoda, Anomura). Revista Brasileira de Biologia, 38(2): 383-390.

Santos, S.; Bartholomei-Santos, M.L.; Pérez-Losada, M. and Crandall, K.A. 2013. New species and records of the genus Aegla Leach 1820 from the West-Central region of Rio Grande do Sul, Brazil. Nauplius, 21(2): 211-223.

Santos, S.; Bond-Buckup, G.; Buckup, L.; Bartholomei-Santos, M.L.; Pérez-Losada, M.; Jara, C.G. and Crandall, K.A. 2015. Three new species of Aeglidae (Aegla Leach, 1820) from Paraná state, Brazil. Journal of Crustacean Biology, 35(6): 839-849.

Santos, S.; Bond-Buckup, G.; Buckup, L.; Loureiro, T.G.; Gonçalves, A.S.; Verdi, A.; Scarabino, F. and Clavijo, C. 2014. The Aeglidae of Uruguay (Decapoda, Anomura), with the description of a new species of Aegla. Crustaceana Monographs, 19:195-205.

Santos, S.; Bond-Buckup, G.; Buckup.,L.; Pérez-Losada, M.; Finley, M. and Crandall, K.A. 2012. Three new species of Aegla (Anomura) freshwater crabs from the Upper Uruguay River Hydrographic Basin in Brazil. Journal of Crustacean Biology, 32(4):529-540.

Santos, S.; Bond-Buckup, G.; Pérez-Losada, M; BartholomeiSantos, M.L. and Buckup, L. 2009. Aegla manuinflata, a new species of freshwater anomuran (Decapoda: Anomura: Aeglidae) from Brazil, determined by morphological and molecular characters. Zootaxa, 2088: 31-40.

Schmitt, W.L. 1942. The species of Aegla, endemic South American fresh-water crustacean. Proceedings of the United States National Museum, 91: 431-524.

Silva-Castiglioni, D.; Barcelos, D.F. and Santos, S. 2006. Crescimento de Aegla longirostri Bond-Buckup and Buckup (Crustacea, Anomura, Aeglidae). Revista Brasileira de Zoologia, 23: 408-413.

Silva-Gonçalves, R.; Bond-Buckup, G. and Buckup, L. 2009. Crescimento de Aegla itacolomiensis (Crustacea, Decapoda) em um arroio da Mata Atlântica no sul do Brasil. Iheringia, Série Zoologia, 99(4): 397-402.

Swiech-Ayoub, B.P. and Masunari, S. 2001a. Flutuações temporal e espacial de abundância e composição de tamanho de Aegla castro Schmitt (Crustacea, Anomura, Aeglidae) no Buraco do Padre, Ponta Grossa, Paraná, Brasil. Revista Brasileira de Zoologia, 18(3): 1003-1017.

Swiech-Ayoub, B.P. and Masunari, S. 2001b. Biologia reprodutiva de Aegla castro Schmitt (Crustacea, Anomura, Aeglidae) no Buraco do Padre, Ponta Grossa, Paraná, Brasil. Revista Brasileira de Zoologia, 18(3): 1019-1030.

Trevisan, A. and Santos, S. 2011. Crescimento de Aegla manuinflata (Decapoda, Anomura, Aeglidae) em ambiente natural. Iheringia, Série Zoologia, 101(4): 336-342. 
Trevisan, A. and Santos, S. 2012. Morphological sexual maturity, sexual dimorphism and heterochely in Aegla manuinflata (Anomura). Journal of Crustacean Biology, 32(4): 519-527.

Türkay, M. 1972. Neue Hohlendekapoden aus Brasilien (Crustacea). Revue Suisse de Zoologie, 79(15): 415-418.
Viau, V.E.; López-Greco, L.S.; Bond-Buckup, G. and Rodríguez, E.M. 2006. Size at the onset of sexual maturity in the anomuran crab, Aegla uruguayana (Aeglidae). Acta Zoologica, 87: $253-264$.

Zar, J.H. 1996. Biostatistical Analysis. New Jersey, Prentice Hall, XXVI+662p. 